\title{
Relevância clínica e biológica das alterações do gene e proteína p53 nas leucemias
}

\author{
Clinical and biological relevance of 553 gene and protein alterations in leukemias
}

Geraldo B. Cavalcanti. Júnior

\section{Orientador}

Raquel C. Maia

\section{Resumo}

As mutações do gene TP53 e/ou inativação da proteína p53 são as alterações genéticas mais comuns nas neoplasias de humanos. Nas leucemias, estas alterações são observadas com menor freqüência, predominando nas formas mais graves da doença e nos casos resistentes ao tratamento. O objetivo desse trabalho foi avaliar a expressão da proteína p53 em diversos tipos de leucemias e a mutação do gene TP53 nos pacientes com leucemia mielóide crônica (LMC). Foram avaliadas amostras de sangue periférico e de medula óssea de 64 pacientes com leucemia linfóide crônica (LLC), 43 com leucemia mielóide aguda (LMA), 44 com leucemia linfóide aguda (LLA) e 72 com LMC. A pesquisa da proteína p53 foi realizada pela citometria de fluxo (CF) após marcação com anticorpo monoclonal anti-p53 e a detecção da mutação do gene TP53 para os éxons 5 a 9 pelo polimorfismo conformacional de fita simples (SSCP). Adicionalmente foram obtidos dados clínicos e laboratoriais referentes aos pacientes, tendo sido também investigado o fenótipo de resistência a múltiplas drogas: expressão da glicoproteína $\mathrm{P}(\mathrm{gpP})$, proteína relacionada a resistência a múltiplas drogas (MRP) e o teste de efluxo da rhodamina-123 além da expressão das proteínas MDM2, p16 e Bcl-2 e do antígeno Ki-67 por CF. Paralelamente, foram testados linfócitos de 40 indivíduos sadios e células de diversas linhagens tumorais que serviram como controle de marcação negativa e positiva para a proteína p53 por CF. A expressão da proteína p53 foi detectada em 63/223 amostras dos pacientes: 14/64 LLC (21,9\%), 13/44 LLA (29,5\%), 19/43 LMA (44,2\%) e 17/72 LMC $(23,6 \%)$, com níveis mais acentuados nas fases avançadas de LLC, LLA e LMC. As alterações do SSCP foram observadas em 11/71 casos de LMC estando mais presentes na fase acelerada e de crise blástica da doença, correlacionando-se com a expressão da proteína p53 na maioria dos casos. Observamos correlação entre a expressão das proteínas p53 e gpP na LMC e LMA; p53 e MRP na LMC, LLC e LMA; p53 e Bcl-2 na LMC e LMA; p53 e MDM2 na LLA, LMA e LLC; p53, e p16 na LLA e a expressão da p53 e o fenótipo funcional MDR na LMC. Houve, também, correlação entre a expressão da proteína p53 e alguns fatores prognósticos desfavoráveis: tempo de duplicação de linfócitos, expressão de CD38, níveis séricos de desidrogenase lática e $\beta 2$ microglobulina e plaquetopenia na LLC. Na LMC houve correlação entre a expressão da p53 com a plaquetopenia, contagem de blastos no sangue periférico maior que $30 \%$, esplenomegalia e hepatomegalia. Na LMA observou-se correlação entre a expressão da p53 com a plaquetopenia e anemia severa. Nossos dados mostram que a expressão da proteína p53 foi observada em todos os tipos de leucemias, entretanto, a sua presença predominou nas formas mais graves da doença, sugerindo que essa proteína possa ser um indicador de agravamento da evolução clínica.

Palavras-chave: Gene TP53, proteína p53, leucemias.

Trabalho de tese de doutorado desenvolvido no Laboratório de Hematologia Celular e Molecular do Serviço de Hematologia do Instituto Nacional de Câncer (Inca/RJ), defendida aprovada no programa de Pós-Graduação em Biologia Celular e Molecular da Fundação Oswaldo Cruz (Fiocruz/RJ) no dia 27 de agosto de 2004.

Correspondência para: Geraldo Barroso Cavalcanti Júnior

Disciplina de Imunologia Clínica - Departamento de Análises Clínicas e Toxicológicas - Faculdade de Farmácia

Centro de Ciências da Saúde - Universidade Federal do Rio Grande do Norte

Rua General Gustavo Cordeiro de Farias $\mathrm{S} / \mathrm{N}$

CEP: 59010-180 - Natal-RN

E-mail: gbcjunior@hotmail.com 


\section{Summary}

A mutation of the TP53 gene and inactivation of the p53 protein are the most common alterations observed in human tumors. In leukemias these alterations are not very frequent, but they prevail in more severe or refractory cases. The objective of this study was to evaluate the $\mathrm{p} 53$ protein expression in leukemias and the TP53 gene mutations in patients with chronic myeloid leukemia. Peripheral blood and bone marrow samples from 64 patients with chronic lymphoid leukemia (CLL), 43 with acute myeloid leukemia (AML), 44 with acute lymphoid leukemia (ALL) and 72 with chronic myeloid leukemia (CML) were evaluated. Flow cytometry was performed after labeling with the anti-p53 monoclonal antibody to study the p53 protein. The TP53 gene mutations to exons 5 to 9 were detected by single strand conformational polymorphism (SSCP). Additionally, clinical and laboratorial data from patients were collected and the multidrug resistance phenotypes were investigated including the P-glycoprotein (Pgp) expression, the multidrug resistant related protein (MRP) and the rhodamine 123 efflux test. The expression of the MDM-2, p16 and Bcl-2 proteins and the Ki-67 antigen were evaluated by flow cytometry. Lymphocytes from 40 healthy donors and tumor lineage cells were used as positive and negative controls for the p53 protein comparison using flow cytometry. The expression of the p53 protein was observed in 63/223 samples: 14/64 CLL (21.9\%), 13/44 ALL (29.5\%), 19/43 AML (44.2\%) and 17/72 CML (23.6\%) with the highest levels in the advanced phases of CLL, ALL and CML. SSCP alterations were observed in 11/71 samples of CML, most of which were in the accelerated and the blastic crisis phases of the disease and these alterations were correlated with the p53 protein expression in most cases. Correlations between p53 and the Pgp expression were observed in CML and AML; p53 and MRP in CML, CLL and AML; p53 and Bcl-2 in CML and AML; p53 and MDM-2 in ALL, AML and CLL; p53 and p16 in ALL and the p53 expression and MDR functional phenotype in CML. We also observed correlations between the p53 protein expression and some unfavorable prognostic factors: lymphocyte duplication time, CD38 expression, serum levels of lactic dehydrogenase and $\beta 2$ microglobulin and thrombocytopenia in CLL; thrombocytopenia, the blast count in peripheral blood higher than $30 \%$ and hepatosplenomegaly in CML; thrombocytopenia and severe anemia in AML. Our data show that the p53 protein expression was observed in all kinds of leukemias. However, its presence was higher in the severe forms of the diseases, suggesting that this protein might be used as an indicator of aggravation in the clinical evolution.

Key Words: TP53 gene, p53 protein, leukemias

Avaliação: A Revista Brasileira de Hematologia e Hemoterapia publica os resumos e abstracts de teses da área apresentados em universidades que tenham programas de pós-graduação reconhecidos pelo MEC/Capes e considera a obtenção do título suficiente para sua publicação na forma como se propõe a seção.

Recebido: 28/11/2004

Aceito após modificações: 03/12/2004 